\title{
Socioeconomic status and children's need for hospital services. Implications for need-based resource allocation models
}

\author{
ODDVAR KAARB $\varnothing \mathrm{E}^{1, *}$ \\ FREDRIK CARLSEN ${ }^{2}$ \\ ${ }^{1}$ Department of Health Management and Health Economics, University of Oslo, Norway \\ ${ }^{2}$ Department of Economics, Norwegian University of Science and Technology, Norway
}

\begin{abstract}
We investigate whether parents' socioeconomic status affects children's need for hospital services, and potential implications for need-based resource allocation models. Data are from somatic hospital stays by children below the age of 11 in Norway in 2011. Socioeconomic status is measured by parents' educational level or income. We find that the educational gradient is dominating the income gradient, and the effects are strong: Hospital expenditures of a child whose mother (father) has not completed secondary education are $51 \%$ (42\%) higher than average expenditures. The effect of parents' educational level is strongest for the youngest children and is mainly due to emergency care. Since we find a negative correlation between the educational attainment and hospital expenditures, we argue that education level of parents should be included in the need-based resource allocation model.
\end{abstract}

JEL classification: I14

Key words: socioeconomic status, children's need for hospital services, resource allocation models

\section{Introduction}

A common feature of most health care system is the devolved responsibility for arranging health care to purchasers. These purchasers - often called health plans - can be local government (Sweden and Denmark), local administrative boards (England and Norway) or sickness funds (Belgium, the Netherlands, and Germany). The health plans are responsible for commissioning and/or producing specific types of health care for a designated population (e.g. defined by geography or voluntary enrollment) over a given time period.

Often health plans receive their funding through some form of capitation system. That is, each plan member's contribution to the plan's budget for a given time period is based on his or her expected expenditure needs for that period. Since plan members' expected expenditure typically vary considerably with age, morbidity and socioeconomic

* Correspondence to: Oddvar Kaarbøe, Department of Health Management and Health Economics, University of Oslo, 0788, Oslo, Norway. E-mail: oddvar.kaarboe@medisin.uio.no

Published: Online September 2017. In print December 2017. dx.doi.org/10.5617/njhe.3581 
status, capitation systems seek to adjust members' per capita contribution to reflect the relative expenditure needs. ${ }^{1}$

Adjustments of members' per capita contribution are common in the Scandinavian countries and in UK. Typically, age, health status, socioeconomic statues, and sometimes sex, constitute most of the capitation formula. Often adjustment for unavoidable excess costs of delivering health care in different geographical areas is also included (with Denmark as the exception). ${ }^{2}$

While many capitation systems have been refined the latter years and include socioeconomic status for the adult population, the relationship between socioeconomic status and children's need for health services are typically left out. We believe that this is a shortcoming of the current capitation models as there is increasing evidence that support the link between lower socioeconomic status and negative health outcomes at birth and throughout the life span. These relationships relate both to psychological and somatic health. ${ }^{3}$

The relationship between children's health outcome and socioeconomic inequalities is typically studied by using the parents' socioeconomic status. Grøholt (2003) considers a survey from 1996 among 10000 Nordic children between the age of 2 and 17 years, and their use of health services. About 3000 children were Norwegian, and the response rate was about $64,5 \%$. The parents answered either on behalf of their children or together with their children. The respondents were asked about their use of general practitioners and specialist services during the last three months. Children from families with high salaries had a higher probability of seeing a specialist compared to children from families of unskilled workers. This result holds true both for children with and without chronic diseases. The socioeconomic gradient related to specialist visits was strongest for children with chronic diseases. The authors find no socioeconomic gradient for visits to general practitioners.

Statistics Norway (2012) investigates immigrants' use of their regular general practitioners' services based on Norwegian data from 2010. An immigrant is defined as a person born outside Norway by non-Norwegian parents. The data shows that immigrants use their regular GP services less than the general population, and that the difference is largest for children between 0-5 years: while two of three children from the general population visited their regular GP, the corresponding number for immigrant children is one of three.

Finnvold (2009) analyses asthmatic children's use of health services in Norway using a survey of parents of all children receiving benefits. He finds that children from higher socioeconomic families were both diagnosed quicker and more often obtained specialist treatment. He concludes that differences in need cannot explain the socioeconomic gradient in use.

\footnotetext{
${ }^{1}$ From the Grossman model (Grossman, 1972) and research within epidemiology we have learned that demand for health care is determined by health status, demography and socioeconomic factors. Empirical research what investigates access to and use of health services support this hypothesis, see e.g. van Doorslaer and Masseria (2004) and Grasdal and Monstad (2011).

${ }^{2}$ See Indenrigs- og Sundhetsministeriet (2011); Ministry of Health and Care Services (2008); Information Services Division, NHS National Services Scotland (2015); NHS England Analytical Services (2014); and Statistics Sweden (2015) for details of the capitation formulas in these countries.

${ }^{3}$ Lower levels of socioeconomic status have been found to be associated with e.g. higher incidence of Alzheimer's disease later in life (Fratiglioni et al, 2007) and higher physiological markers of chronic stressful experiences for adolescents (Chen and Paterson, 2006). When it comes to somatic health, lower levels of socioeconomic status have been found to be associated with higher rates of cardiovascular disease for adults (Steptoe and Marmot, 2004).
} 
Mörk et al. (2014) investigate the relationship between parents' socioeconomic status and children's use of hospital services in Sweden. Based on data from 2006-2009 they find that children from families with highest socioeconomic status - measured either by income or education - have 40-45 percentage lower risk of being treated inpatient compared with children from the lowest socioeconomic families. The socioeconomic gradient is highest for diseases in the respiratory organ and for psychiatric diseases, respectively $80 \%$ and $60 \%$, while the socioeconomic gradient is about $40 \%$ for injuries.

Reiss (2013) reviews 55 studies on the relationship between socioeconomic disparities and mental health problems in childhood and adolescence published in English or German between 1990 and 2011. Fifty-two studies indicated an inverse relationship between socioeconomic status and mental health problems of children and adolescents. Socioeconomically disadvantaged children and adolescents were two to three times more likely to develop mental health problems, and low socioeconomic status that persisted over time was strongly related to higher rates of mental health problems. Kahl et al. (2007) studies children's accidents and accident protective measures using the Health Interview and Examination Survey for Children and Adolescents From Germany. The parents of 16,706 children (aged 1-17 years) were asked about their children's injuries within the last 12 months that were medically treated, and about accident mechanisms, consequences of injuries, and ambulatory and hospital treatment. In addition, parents and children aged 11 to 17 years $(\mathrm{n}=6813)$ were asked to give information on protective measures. Socioeconomic status did not affect the rate of domestic accidents, leisure and sports injuries. However, children from families with lower socioeconomic status showed higher rates of traffic accidents than children from families with higher socioeconomic status. Low socioeconomic status and migration background were also associated with lower use of protective measures (helmets and protective clothes). Ellsäßer (2006) also finds that children from ethnic minorities and low status families are the groups most at risk in terms of road traffic accidents and scalds. Finally, Geyer et al. (2002) study how parents' socioeconomic statues measured by occupational position and parents' nationality affect children's hospitalization risks using data from German statutory health insurance between 1987 and 1996. The authors find that social inequalities in terms of hospital admissions attributable to acute diseases were rather small. The only exception was infections of the respiratory organs. However, length of stay in hospital was significantly related to socioeconomic position for infections of the upper respiratory tract and infections of the respiratory organs, with children and adolescents with the lowest socioeconomic background having spent the longest periods in hospital.

To investigate whether parents' socioeconomic status affects children's need for somatic hospital services, and potential implications for need-based resource allocation models, we use data from hospital stays by children below the age of 11 in Norway in 2011. Socioeconomic status is measured by parents' income or educational level. We believe we are the first authors that investigate this relationship using Norwegian register data of hospital stays.

We find that the educational gradient is dominating the income gradient, and the effects are strong: Hospital expenditures of a child whose mother (father) has not completed secondary education are $51 \%(42 \%)$ higher than average expenditures. The effect of parents' educational levels is strongest for the youngest children (below the age of 6). When we split hospital expenditures among emergency care and planned treatment, we find that the education gradient is mainly due to emergency care. For the youngest children, the relationship between parents' education level and planned treatment is actually the opposite: higher education level is associated with higher hospital expenditures. Our interpretation is 
that parents with higher education are better able to plan preventive and curative treatments, which reduces the need for emergency care.

\section{The institutional setting}

The Norwegian health care sector is organized into primary and secondary health care sectors. The former is the responsibility of municipalities while the latter is the responsibility of the central government.

The primary care sector consists of primary care physicians and long term care. Primary care physicians are mostly private practitioners. A regular General Practitioner Scheme was implemented in 2001. It requested that each inhabitant should be listed with a GP. Over $95 \%$ of the inhabitants complied with the request. The GP provides the patient's initial medical services in a nonemergency case.

The secondary health sector is organized through four regional health authorities (RHA). ${ }^{4}$ The authorities have the responsibility for commissioning and financing health care services for the population in the region, and providing these services. The provision takes place mainly through its own hospitals, or is supplied by independent private specialists.

There is a referral system for planned treatment as patients have to visit a GP to get a referral to a hospital, if such (planned) treatment is needed. In the case the patient needs emergency treatment, he or she will be treated directly at the hospital.

The RHAs are financed with a combination of a risk-adjusted block grant (capitation) and activity-based financing related to somatic care. The share of activity-based financing has varied between $40 \%$ and $50 \%$ of the total budget (to somatic care). Currently the share is $50 \%$, while in 2011 the share was $40 \%$. Other specialized health care services are funded by risk-adjusted block grant. Since the somatic sector counts for about $75 \%$ of the RHAs' total budget, the total share of the budget funded by capitation was about $70 \%$.

The criteria used in the capitation block grant are based on analyses performed by a Norwegian public committee ${ }^{5}$ that delivered its report in 2008 (NOU 2008:2). After a period with a public hearing the central government suggested a model for the Parliament, which was approved. ${ }^{6}$

The criteria used in the capitation model for somatic care are age $(58 \%)$ and the following health and social variables (42\%): Mortality, employment status, receiving rehabilitation compensation, level of education, municipal socio-economic index, and an index for climate and latitude. The health related variables (mortality, employment status and rehabilitation compensation) are estimated and allocated based on the shares of the adult population (18-67 years) that meets the criteria. Similarly, the socioeconomic variable "level of education" is estimated and allocated based on the expenditure shares of individuals aged 20-59 years with only primary education.

\section{Data and empirical specification}

Our data source of hospital treatment is the National Patient Register for the 2011. The register has information about hospital, referral and admission dates, primary and secondary diagnoses, patient's birth year and gender and patient's place of residence (municipality or

\footnotetext{
${ }^{4}$ Hagen and Kaarboe (2006) and Magnussen et. al. (2007) provide for more detailed descriptions of the Norwegian hospital sector.

${ }^{5}$ The government appoints a public committee by a royal decree.

${ }^{6}$ Magnussen (2010) gives a detailed overview of the process of developing and implementing the capitation model.
} 
city district) for all patient episodes (both inpatient treatment and outpatient treatment covered by the DRG-system) in somatic hospitals. ${ }^{7}$

Information about education level and income cannot be linked to patients at the individual level as personal identifier is not available for this project. However, since the register has information about birth year, gender and place of residence, patient episodes can be uniquely linked to population cells that combine age, gender and municipality/district. For the mothers and fathers of the children in the population cells, we used administrative registers of Statistics Norway to compute average cell income and cell population shares with respectively i) more than three years of tertiary education, ii) less than four years of tertiary education, iii) secondary education and iv) primary or less education. Tertiary education is defined as minimum one year of completed education at college/university and secondary education is defined as minimum one year at secondary school. Income is defined as the sum of wages, net capital income and benefits less taxes. The analysis covers children aged 0-10 years (birth years 2001-2011). ${ }^{8}$

There were 430 Norwegian municipalities in 2011. We dropped two municipalities that merged at the end of the year and collected information from 34 districts in the four largest cities, producing a total of 458 geographical units (424 municipalities and 34 city districts).

The maximum possible number of cells with combinations of municipality/district, birth year and gender is $10076\left(=458^{*} 11 * 2\right)$. However, 62 of the cells were empty in 2011, leaving the remaining 10014 cells as our observation units.

There are approximately 670000 children below 11 in Norway, and a population cell has on average 67 children. Since population size varies considerably between municipalities, there are large variations in the number of children in each cell. 15 cells have only one child, 155 cells have two children, 1998 cells have 3-10 children, whereas 2153 cells have more than 100 children, and 45 cells have more than 500 children.

Table 1 presents the variables and the summary statistics for the data set. The population cells are weighted with the number of children in the cells as weights. Hence, the average values express the national averages.

Our main dependent variable is total hospital expenditures (NOK) incurred by cell members during 2011 scaled by the average number of cell members (the average of beginning-of-year and end-of-year cell members). Total expenditures are the sum of patient episodes multiplied with the respective DRG-prices. Average per capita expenditures in 2011 were NOK 5822 (or approximately €623), and emergency care comprised almost $60 \%$ of the expenditures. Expenditures were zero in 445 (mostly small) population cells $(4.4 \%$ of the total number of cells), implying that no patient episodes were recorded during 2011 in these cells.

For mothers (fathers), the mean cell share with at least one year of tertiary education is $0.50(0.37) .12 \%(13 \%)$ of the mothers (fathers) have at least four years of tertiary education, and the similar shares with at most primary education are $16 \%$ (mothers) and $17 \%$ (fathers). Fathers have about $55 \%$ more income than mothers.

To investigate how parents's socioeconomic status affects children's need for hospital services we run regressions explaining per capita hospital expenditures as a function of socioeconomic status, fixed effects for municipalities/districts and separate birth year fixed effects for boys and girls. Place fixed effects are included to control for differences in supply of health care services, including travel time to hospital, as we don't expect supply factors

\footnotetext{
${ }^{7}$ Notice that we do not have data for psychiatric hospital stays.

${ }^{8}$ We find no socioeconomic gradient when we analyze the age group 11-18 years.
} 
to vary much within municipalities/districts. Our specification implies that the effects of parents' socioeconomic status on expenditures are identified by variation between children of different age within the same municipality/district, which precludes identification of effects for narrow age groups.

Table 1: Summary statistics. Children 0-10 years. 10014 cells. Cells are weighted with number of children in the cells.

\begin{tabular}{llll}
\hline & Mean & St.dev. & Max / Min \\
\hline Expenditure (NOK) per capita & 5822 & 10179 & 552566 / 0 \\
Exp per capita, emergency care & 3423 & 8022 & $534019 / 0$ \\
Exp per capita, planned treatment & 2399 & 4681 & $308938 / 0$ \\
& & & \\
Mother's education: & & & \\
Share with primary education or less & 0.156 & 0.075 & $1 / 0$ \\
Share with secondary education & 0.305 & 0.103 & $1 / 0$ \\
Share with <4 years of tertiary educ. & 0.387 & 0.087 & $1 / 0$ \\
Share with 4>= years of tertiary educ. & 0.116 & 0.091 & $1 / 0$ \\
Missing information & 0.037 & 0.033 & $0.75 / 0$ \\
& & & \\
Father's education: & & & $1 / 0$ \\
Share with primary education or less & 0.170 & 0.078 & $1 / 0$ \\
Share with secondary education & 0.432 & 0.139 & $1 / 0$ \\
Share with <4 years of tertiary educ. & 0.241 & 0.079 & $1 / 0$ \\
Share with 4>= years of tertiary educ. & 0.131 & 0.098 & $0.67 / 0$ \\
Missing information & 0.026 & 0.027 & $8.5 / 0.3$ \\
& & & $30.7 / 1.0$ \\
Average income, mother (10 5 NOK) & 3.78 & 0.61 & $1 / 0$ \\
Average income, father (10 NOK) & 5.87 & 1.60 & $1 / 0$ \\
Share of western immigrants & & & 0.0203 \\
Share of non-western immigrants & 0.0169 & 0.1068 & \\
\hline
\end{tabular}

We include the cell shares of western and non-western immigrants ${ }^{9}$ as covariates to control for any differences between immigrants and natives in demand for health services. The other criteria in the capitation formula are captured by the municipal/district fixed effects.

The regression models we thus estimate are variants of:

$$
\begin{aligned}
\operatorname{Exp}=\overrightarrow{\delta_{\text {Munl }}}+ & \overrightarrow{\delta_{1}} \text { B.YEAR }+\overrightarrow{\delta_{2}} \text { B.YEAR } \times S E X+\overrightarrow{\delta_{3}} \text { EDU.SHARE } \\
& +\overrightarrow{\delta_{4}} \text { EDU.SHers } \\
& +\delta_{7} \text { WESTERN }+\delta_{8} N . \text { WESTERN }+\epsilon
\end{aligned}
$$

The scalars $\delta_{5}-\delta_{8}$, and the vectors $\overrightarrow{\delta_{\text {Munl }}}, \overrightarrow{\delta_{1}}-\overrightarrow{\delta_{4}}$ are parameters to be estimated. Standard errors are clustered at the municipality/district level.

\footnotetext{
${ }^{9}$ Immigrants from Africa, Asia except Japan, Latin America and Eastern-Europe.
} 


\section{Results}

The results are presented in Tables 2-8. Table 2 investigates the effect of parents' education on per capita hospital expenditures, while Table 3 analyzes the effects of parental education and income. In Table 4, we split the children into two groups, 0-5 years and 6-10, to investigate if the effects of educational level vary between the youngest and oldest children. Tables 5-6 provide separate analyses for emergency and planned treatment, and Tables 7-8 present the results of some sensitivity analyses.

Table 2: $\quad$ Effect of parental education on expenditure (NOK) per capita. Children aged 0-10 years. Weighted least squares with cell population as weights.

\begin{tabular}{|c|c|c|c|}
\hline & (1) & (2) & (3) \\
\hline \multicolumn{4}{|l|}{ Mother's education: } \\
\hline Share with primary education or less & - & & - \\
\hline Share with secondary education & $\begin{array}{l}-2746(-2.70) \\
{[-4746,-746]}\end{array}$ & & $\begin{array}{l}-2477(-2.41) \\
{[-4498,-456]}\end{array}$ \\
\hline Share with $<4$ years of tertiary ed. & $\begin{array}{l}-2245(-1.81) \\
{[-4689,198]}\end{array}$ & & $\begin{array}{l}-1529 \\
{[-4071,1014]}\end{array}$ \\
\hline Share with $4>=$ years of tertiary ed. & $\begin{array}{l}-5722(-2.58) \\
{[-10085,-1360]}\end{array}$ & & $\begin{array}{l}-4293(-1.98) \\
{[-8551,-35]}\end{array}$ \\
\hline \multicolumn{4}{|l|}{ Father's education: } \\
\hline Share with primary education or less & & - & - \\
\hline Share with secondary education & & $\begin{array}{l}-1694(-1.56) \\
{[-3828,440]}\end{array}$ & $\begin{array}{l}-1392(-1.27) \\
{[-3550,766]}\end{array}$ \\
\hline Share with $<4$ years of tertiary ed. & & $\begin{array}{l}-2950(-2.15) \\
{[-5651,-249]}\end{array}$ & $\begin{array}{l}-2483(-1.72) \\
{[-5325,359]}\end{array}$ \\
\hline Share with $4>=$ years of tertiary ed. & & $\begin{array}{l}-4666(-2.38) \\
{[-8517,-815]}\end{array}$ & $\begin{array}{l}-3550(-1.87) \\
{[-7235,135]}\end{array}$ \\
\hline Share of western immigrants & & $\begin{array}{l}-2013(-0.72) \\
{[-7393,3367]}\end{array}$ & $\begin{array}{l}-1994(-0.71) \\
{[-7486,3498]}\end{array}$ \\
\hline Share of non-western immigrants & & $\begin{array}{l}-3646(-2.61) \\
{[-7145,-146]}\end{array}$ & $\begin{array}{l}-4296(-2.36) \\
{[-7880,-711]}\end{array}$ \\
\hline $\begin{array}{l}\text { Fixed effects: } \\
\text { Birth year x Sex } \\
\text { Municipality }\end{array}$ & & & \\
\hline $\begin{array}{l}\text { Observations } \\
\text { Adjusted } \mathrm{R}^{2}\end{array}$ & $\begin{array}{l}10014 \\
0.751 \\
\end{array}$ & $\begin{array}{l}10014 \\
0.751 \\
\end{array}$ & $\begin{array}{l}10014 \\
0.751 \\
\end{array}$ \\
\hline
\end{tabular}


Table 2: Continued.

\begin{tabular}{|c|c|c|c|}
\hline & (4) & (5) & (6) \\
\hline \multicolumn{4}{|l|}{ Mother's education: } \\
\hline \multirow[t]{2}{*}{ Share with primary education or less } & $2776(2.67)$ & & $2390(2.27)$ \\
\hline & {$[734,4818]$} & & {$[322,4457]$} \\
\hline Share with secondary education & - & & - \\
\hline Share with $<4$ years of tertiary ed. & - & & - \\
\hline Share with $4>=$ years of tertiary ed. & - & & - \\
\hline \multicolumn{4}{|l|}{ Father's education: } \\
\hline \multirow[t]{2}{*}{ Share with primary education or less } & & $2304(2.19)$ & 1844 (1.73) \\
\hline & & {$[239,4369]$} & {$[-246,3933]$} \\
\hline Share with secondary education & & - & - \\
\hline Share with $<4$ years of tertiary ed. & & - & - \\
\hline Share with $4>=$ years of tertiary ed. & & - & - \\
\hline \multirow[t]{2}{*}{ Share of western immigrants } & $-2829(-1.04)$ & $-2525(-0.94)$ & $-2697(-1.00)$ \\
\hline & {$[-8150,2493]$} & {$[-7795,2745]$} & {$[-8015,2622]$} \\
\hline \multirow[t]{2}{*}{ Share of non-western immigrants } & $-4066(-2.24)$ & $-3472(-1.96)$ & $-4258(-2.36)$ \\
\hline & {$[-7640,-493]$} & {$[-6948,5]$} & {$[-7806,-709]$} \\
\hline \multicolumn{4}{|l|}{ Fixed effects: } \\
\hline \multicolumn{4}{|l|}{ Birth year x Sex } \\
\hline \multicolumn{4}{|l|}{ Municipality } \\
\hline Observations & 10014 & 10014 & 10014 \\
\hline Adjusted $\mathrm{R}^{2}$ & 0.751 & 0.751 & 0.751 \\
\hline
\end{tabular}

Coefficients, t-values (in parentheses) and $95 \%$ confidence intervals (in brackets). Cell share with missing information about education level included in regressions. Standard errors are clustered at municipality/district level.

From Table 2 we see that the effects of education are significant and strong. The higher the parents' level of education, the less hospital expenditures are generated by the children. This result holds for both mothers and fathers. The strength of the educational gradient can be illustrated as follows: Consider two municipalities A and B that are equal on all aspects except the mothers' education level. The share of mothers with primary education or less is equal to one in municipality $\mathrm{A}$, and the share of mothers with at least four years of education is equal to one in municipality $\mathrm{B}$. In this case predicted expenditures on hospital care per child below the age of 11 are NOK 5722 (€612) lower in the latter municipality (based on the first column of Table 2). If the two municipalities are equal in all respects except that municipality A has only fathers with primary education or less and municipality B has only fathers with at least four years of education, per capita expenditures on hospital care for children are 4666 NOK (€499) lower in municipality B (second column of Table 2). When both parents' education levels are included as covariates, neither clearly outperforms the other (third column of Table 2).

F-tests applied to columns 1-3 reject neither that the coefficients of the three education variables of mothers are identical, nor that the education variables of fathers are identical. We have therefore estimated equations that include only the shares of mothers and fathers with primary education or less (columns 4-6 of Table 2). We see that the effect of 
the share of mother's with primary education or less is always positive and significant, whereas the effect of the father's share is also positive, but somewhat smaller in magnitude and borderline significant when included together with mother's share. Columns (4) and (5) imply that - conditional on other covariates - hospital expenditures of a child whose mother has not completed secondary education are $51 \%$ higher than average expenditures, whereas a child of a father without secondary education incur $42 \%$ higher expenditures than average.

In Table 3, we have included both parental incomes and parental shares without secondary education as explanatory variables. The coefficient of father's income is small in absolute magnitude and insignificant. The coefficient of mother's income is positive and significant, but the absolute effect is not very strong. Hence, parental education level is more important than parental income for children's hospital expenditures, whereas mother's education level is somewhat more important than that of the father.

\section{Table 3: Effects of parental education and income on expenditure (NOK) per capita. Children 0-10 years. Weighted least squares with cell population as weights.}

(1)

$3283(3.09)$

$[1198,5368]$

Share with more than primary ed.

Father's education:

Share with primary education or less

Mother's education:

Share with primary education or less

(2)

Share with more than primary ed.

Average income, mother (105 NOK)

$586(3.18)$

[199, 973]

Average income, father (105 NOK)

$86(1.18)$

$[-56,23]$

Fixed effects:

Birth year x Sex

Municipality

Observations

10014

10014

Adjusted R ${ }^{2}$

0.752

0.752

Coefficients, t-values (in parentheses) and $95 \%$ confidence intervals (in brackets). Average income in $10^{5}$ NOK/year. Shares of western and non-western immigrants, share with missing information about education level and share with missing information about income included in regressions. Standard errors are clustered at municipality/district level. 
In Table 4, we estimate the effect of parents' education level on two age groups: the youngest children (aged 0-5) and the older children (aged 6-10). The effect of educational level is strongest for the youngest children. Mother's education level affects expenditures on hospital care in both age groups, but the effect is more than twice as strong for the youngest children. Father's education affects only the youngest children; for the older children, father's education level is insignificant.

\section{Table 4: Results for age groups. Dependent variable: Expenditure (NOK) per capita. Weighted least squares with cell population as weights.}

\begin{tabular}{|c|c|c|c|c|}
\hline & $0-5$ years & 6-10 years & $0-5$ years & 6-10 years \\
\hline \multicolumn{5}{|l|}{ Mother's education: } \\
\hline \multirow[t]{2}{*}{ Share with primary education or less } & $3955(2.23)$ & $1463(2.34)$ & & \\
\hline & {$[467,7444]$} & {$[234,2691]$} & & \\
\hline Share with more than primary ed. & - & - & & \\
\hline \multicolumn{5}{|l|}{ Father's education: } \\
\hline \multirow[t]{2}{*}{ Share with primary education or less } & & & $3971(2.16)$ & $-202(-0.32)$ \\
\hline & & & {$[351,7591]$} & {$[-1451,1047]$} \\
\hline Share with more than primary ed. & & & - & - \\
\hline \multicolumn{5}{|l|}{ Fixed effects: } \\
\hline \multicolumn{5}{|l|}{ Birth year x Sex } \\
\hline \multicolumn{5}{|l|}{ Municipality } \\
\hline Number of cells & 5451 & 4563 & 5451 & 4563 \\
\hline Adjusted $\mathrm{R}^{2}$ & 0.739 & 0.028 & 0.739 & 0.027 \\
\hline
\end{tabular}

Coefficients, t-values (in parentheses) and $95 \%$ confidence intervals (in brackets). Shares of western and nonwestern immigrants and share with missing information about education level included in regressions. Standard errors are clustered at municipality/district level.

We then split the hospital expenses between emergency care and elective care, where elective care is defined as planned treatment where the patient is referred to the hospital by a primary care physician. Emergency care treatments are those where the patient is in need of medical emergencies, and is sent directly to the emergency department at the nearest hospital. The results are presented in Table 5 (mother's education) and Table 6 (father's education). For the youngest children, parental education level affects not only the level of hospital expenditures but also the composition. The point estimates imply that children aged 0-5 of parents with more than primary education spend more on elective hospital care than other children, but much less on acute hospital care. For the older children, we do not find substantial effects of education level on the composition of hospital care expenditures.

We end by providing some sensitivity analyses for the two age groups (Tables 7 and 8). First we exclude cells where more than $10 \%$ of the observations in the cell have unknown educational status. Secondly, we exclude municipalities with more than 10000 inhabitants. Third, we omit population cells with zero hospital expenditures. For all these analyses, the results are basically unchanged compared with the baseline results presented in Table 4; the only exception being that the effect of father's education on children 0-5 years becomes borderline insignificant when larger municipalities are excluded. 
Table 5: Separate analyses for emergency and planned treatment. Mother's education. Dependent variable: Expenditure (NOK) per capita. Weighted least squares with cell population as weights.

\begin{tabular}{|c|c|c|c|c|}
\hline \multirow[t]{2}{*}{ Treatment: } & \multicolumn{2}{|c|}{ Emergency treatment } & \multicolumn{2}{|c|}{ Planned treatment } \\
\hline & $0-5$ years & $6-10$ years & $0-5$ years & $6-10$ years \\
\hline \multicolumn{5}{|l|}{ Mother's education: } \\
\hline \multirow[t]{2}{*}{ Share with primary education or less } & $5765(2.79)$ & $592(1.63)$ & $-1810(-0.96)$ & $870(2.15)$ \\
\hline & {$[1702,9828]$} & {$[-120,1304]$} & {$[-5499,1880]$} & {$[73,1668]$} \\
\hline Share with more than primary ed. & - & - & - & - \\
\hline \multicolumn{5}{|l|}{ Fixed effects: } \\
\hline \multicolumn{5}{|l|}{ Birth year x Sex } \\
\hline \multicolumn{5}{|l|}{ Municipality } \\
\hline Number of cells & 5451 & 4563 & 5451 & 4563 \\
\hline Adjusted $\mathrm{R}^{2}$ & 0.610 & 0.025 & 0.313 & 0.033 \\
\hline
\end{tabular}

Coefficients, t-values (in parentheses) and $95 \%$ confidence intervals (in brackets). Shares of western and nonwestern immigrants and share with missing information about education level included in regressions. Standard errors are clustered at municipality/district level.

Table 6: Separate analyses for emergency and planned treatment. Father's education. Dependent variable: Expenditure (NOK) per capita. Weighted least squares with cell population as weights.

\begin{tabular}{lllll}
\hline \multicolumn{1}{c}{ Treatment: } & \multicolumn{2}{l}{ Emergency treatment } & \multicolumn{2}{l}{ Planned treatment } \\
& $0-5$ years & 6-10 years & 0-5 years & 6-10 years \\
\hline Father's education: & & & & \\
Share with primary education or less & $6268(3.00)$ & $-290(-0.94)$ & $-2297(-1.36)$ & $88(0.19)$ \\
& {$[2165,9828]$} & {$[-896,315]$} & {$[-5619,1025]$} & {$[-804,980]$} \\
Share with more than primary ed. & - & - & - & - \\
& & & & \\
Fixed effects: & & & & \\
Birth year x Sex & & & & \\
Municipality & & & 5451 & 4563 \\
& 5451 & 4563 & 0.313 & 0.032 \\
Number of cells & 0.610 & 0.026 & & \\
Adjusted R & & & & \\
\hline
\end{tabular}

Coefficients, t-values (in parentheses) and $95 \%$ confidence intervals (in brackets). Shares of western and nonwestern immigrants and share with missing information about education level included in regressions. Standard errors are clustered at municipality/district level. 
Table 7: Sensitivity analysis. Mother's education. Dependent variable: Expenditure (NOK) per capita. Weighted least squares with cell population as weights.

\begin{tabular}{|c|c|c|c|c|}
\hline Age group: & $\begin{array}{l}0-5 \text { years } \\
(1)\end{array}$ & (2) & (3) & (4) \\
\hline \multicolumn{5}{|l|}{ Mother's education: } \\
\hline Share with primary education or less & $\begin{array}{l}3955(2.23) \\
{[467,7444]}\end{array}$ & $\begin{array}{l}4990(2.63) \\
{[1265,8716]}\end{array}$ & $\begin{array}{l}5486(2.95) \\
{[1832,9140]}\end{array}$ & $\begin{array}{l}4076(2.15) \\
{[350,7802]}\end{array}$ \\
\hline Share with more than primary ed. & - & - & - & - \\
\hline \multicolumn{5}{|l|}{$\begin{array}{l}\text { Fixed effects: } \\
\text { Birth year x Sex } \\
\text { Municipality }\end{array}$} \\
\hline $\begin{array}{l}\text { Number of cells } \\
\text { Adjusted } \mathrm{R}^{2}\end{array}$ & $\begin{array}{l}5451 \\
0.739\end{array}$ & $\begin{array}{l}4991 \\
0.732\end{array}$ & $\begin{array}{l}3771 \\
0.528\end{array}$ & $\begin{array}{l}5257 \\
0.742\end{array}$ \\
\hline Age group: & $\begin{array}{l}\text { 6-10 years } \\
\text { (1) }\end{array}$ & (2) & (3) & (4) \\
\hline \multicolumn{5}{|l|}{ Mother's education: } \\
\hline Share with primary education or less & $\begin{array}{l}1465(2.34) \\
{[234,2691]}\end{array}$ & $\begin{array}{l}1485(2.27) \\
{[197,2773]}\end{array}$ & $\begin{array}{l}1495(2.25) \\
{[188,2801]}\end{array}$ & $\begin{array}{l}1645(2.35) \\
{[269,3021]}\end{array}$ \\
\hline Share with more than primary ed. & - & - & - & - \\
\hline \multicolumn{5}{|l|}{$\begin{array}{l}\text { Fixed effects: } \\
\text { Birth year x Sex } \\
\text { Municipality }\end{array}$} \\
\hline $\begin{array}{l}\text { Number of cells } \\
\text { Adjusted } \mathrm{R}^{2}\end{array}$ & $\begin{array}{l}4563 \\
0.028\end{array}$ & $\begin{array}{l}4310 \\
0.026\end{array}$ & $\begin{array}{l}3163 \\
0.012\end{array}$ & $\begin{array}{l}4312 \\
0.027\end{array}$ \\
\hline
\end{tabular}

Coefficients, t-values (in parentheses) and $95 \%$ confidence intervals (in brackets). Shares of western and nonwestern immigrants and share with missing information about education level included in regressions. Standard errors are clustered at municipality/district level.

1) Baseline regression, from Table 4.

2) Missing information about education level for less than $10 \%$ of cell.

3) Municipalities with population $<10000$.

4) Only cells with positive expenditure. 
Table 8: Sensitivity analysis. Father's education. Dependent variable: Expenditure (NOK) per capita. Weighted least squares with cell population as weights.

\begin{tabular}{|c|c|c|c|c|}
\hline Age group: & $\begin{array}{l}0-5 \text { years } \\
(1)\end{array}$ & (2) & (3) & (4) \\
\hline \multicolumn{5}{|l|}{ Father's education: } \\
\hline Share with primary education or less & $\begin{array}{l}3971(2.16) \\
{[351,7591]}\end{array}$ & $\begin{array}{l}4516(2.35) \\
{[733,8299]}\end{array}$ & $\begin{array}{l}3347(1.69) \\
{[-538,7233]}\end{array}$ & $\begin{array}{l}4029(2.05) \\
{[169,7889]}\end{array}$ \\
\hline Share with more than primary ed. & - & - & - & - \\
\hline \multicolumn{5}{|l|}{$\begin{array}{l}\text { Fixed effects: } \\
\text { Birth year x Sex } \\
\text { Municipality }\end{array}$} \\
\hline $\begin{array}{l}\text { Number of cells } \\
\text { Adjusted } \mathrm{R}^{2}\end{array}$ & $\begin{array}{l}5451 \\
0.739\end{array}$ & $\begin{array}{l}5175 \\
0.749\end{array}$ & $\begin{array}{l}3771 \\
0.527\end{array}$ & $\begin{array}{l}5257 \\
0.742\end{array}$ \\
\hline Age group: & $\begin{array}{l}\text { 6-10 years } \\
\text { (1) }\end{array}$ & (2) & (3) & (4) \\
\hline \multicolumn{5}{|l|}{ Father's education: } \\
\hline Share with primary education or less & $\begin{array}{l}-202(-0.32) \\
{[-1451,1047]}\end{array}$ & $\begin{array}{l}-301(-0.45) \\
{[-1629,1026]}\end{array}$ & $\begin{array}{l}-440(-0.65) \\
{[-1776,896]}\end{array}$ & $\begin{array}{l}-188(-0.26) \\
{[-1618,1243]}\end{array}$ \\
\hline Share with more than primary ed. & - & - & - & - \\
\hline \multicolumn{5}{|l|}{$\begin{array}{l}\text { Fixed effects: } \\
\text { Birth year x Sex } \\
\text { Municipality }\end{array}$} \\
\hline $\begin{array}{l}\text { Number of cells } \\
\text { Adjusted } \mathrm{R}^{2}\end{array}$ & $\begin{array}{l}4563 \\
0.027 \\
\end{array}$ & $\begin{array}{l}4310 \\
0.025\end{array}$ & $\begin{array}{l}3163 \\
0.011 \\
\end{array}$ & $\begin{array}{l}4312 \\
0.026 \\
\end{array}$ \\
\hline
\end{tabular}

Coefficients, t-values (in parentheses) and $95 \%$ confidence intervals (in brackets). Shares of western and nonwestern immigrants and share with missing information about education level included in regressions. Standard errors are clustered at municipality/district level.

1) Baseline regression, from Table 4.

2) Missing information about education level for less than $10 \%$ of cell.

3) Municipalities with population $<10000$.

4) Only cells with positive expenditure.

\section{Discussion}

The purpose of this paper is to investigate how parents' socioeconomic status affects children's need for hospital services. Our results show that the effects are strong, and that the higher the parents' level of education, the less health care expenditures are typically incurred by the children. However, for the youngest children, expenditures related to planned treatments increase in the educational level of the mothers. One possible explanation for this result is that higher educated mothers might be able to detect diseases early so that the children are kept out of the emergency rooms and rather get elective hospital 
treatments. Another explanation might be that mothers of higher education are better able to maneuver through primary care gate keeping and thereby getting better access to specialized health care for their children. Finally notice that our results that children of lower socioeconomic statues families have higher emergency care expenditures are consistent with the results of Geyer et al. (2002) and Kahl et al. (2007) that lower socioeconomic status is associated with higher accident rates, lower use of protective measures and longer hospital stays.

An important question is if these expenditures should be compensated in the capitation models. On the one hand one might argue that educational attainment is correlated with health status and therefore with the need for treatment. On the other hand, educational attainment might be correlated with a person's ability to take care of his/her own interests so that well-educated persons receive better services than people with less education. If this is the explanation, it is not that obvious that these expenditures should be compensated. Notice however that if the former explanation were the relevant one, one would expect that there is a negative correlation between educational attainment and use of hospital services. If the latter explanation were the correct one, the correlation would be positive, i.e. higher educational levels go together with higher expenditures. Since we find a negative correlation between the educational attainment and hospital expenditures we will argue that education level of parents should be included in the need-based resource allocation model.

Similarly, how should we treat the result that the share of non-western immigrants correlates to lower somatic hospital services in the capitation models? We do not know about any study indicating that non-western immigrants are healthier than the "native" Norwegians. On the contrary, non-western immigrants typically assess their own health as relatively worse than native Norwegians (Statistics Norway, 2012). Hence, we believe that the negative correlation we find should not be taken into account in the capitation models.

In the present Norwegian allocation model the general education level of the catchment areas of the regional health authorities are included in the allocation formula. If parents' education level is included in the allocation model, new analyses should be carried out to identify the effect of the general education level for the rest of the population such that the overall weight of the education level in the allocation formula becomes correct.

Finally, our data does not include use of somatic hospital services at private specialists that might be a substitute for outpatient hospital services. ${ }^{10}$ If children of parents with higher education receive relatively more services at private specialists our results will overestimate the educational gradient we find. However, most of the services provided are inpatient care where we do not believe private specialist services are a close substitute. The same will also hold true for emergency care.

\section{Acknowledgements}

The paper has benefited from comments following presentations at the Nordic Health Economics Study Group Meeting in Uppsala, 2015, and at the Department of Public Health and Caring Sciences, Uppsala University. We are grateful to two referees and the Editor for helpful comments.

\footnotetext{
${ }^{10} \mathrm{We}$ thank Tor Iversen for pointing out this issue.
} 


\section{References}

Chen, E., and Paterson, L. Q. (2006). Neighborhood, Family, and Subjective Socioeconomic Status: How do They relate to Adolescent Health? Health Psychology, 25(6), 704-714.

Ellsäßer, G. (2006). Epidemiologische Analyse von Unfällen bei Kindern unter 15 Jahren in Deutschland - Ausgangspunkt für die Unfallprävention (Epidemiological Analysis of Injuries Among Children under 15 Years of Age in Germany - The Starting Point for Injury Prevention). Gesundheitswesen 2006; 68(7): 421-428 DOI: 10.1055/s-2006-926917

Finnvold J. E. (2009). The Parents' Story. Socio-Spatial Variation in Health Care in Norwegian Children with Asthma. PhD dissertation (Dr. Polit). University of Oslo.

Fratiglioni, L., Winblad, B., and von Strauss, E. (2007). Prevention of Alzheimer's Disease and Dementia. Major findings from the Kungsholmen Project. Physiology \& Behavior, 92, 98-104.

Geyer S., Peter, R., and Siegrist, J. (2002). Socioeconomic Differences in Children's and Adolescents' Hospital Admissions in Germany: A report based on Health Insurance Data on Selected Diagnostic Categories. Journal of Epidemiology and Community Health 56(2), 109 114.

Grasdal, A., and Monstad, K. (2011). Inequity in the Use of Physician Services in Norway Before and After Introducing Patient Lists in Primary Care. International Journal of Equity in Health 10(25), 3-12.

Grøholt, E.K. (2003). Health and Well-Being of Children in the Nordic Countries: Influence of Socioeconomic Factors in Welfare States. PhD dissertation (Dr. Med.), University of Oslo.

Grossman, M. (1972). On the Concept of Health Capital and the Demand for Health. Journal of Political Economy 80(2), 223-255.

Hagen, T., and Kaarboe, O. (2006). The Norwegian Hospital Reform of 2002: Central Government takes over Ownership of Public Hospitals. Health Policy, 76(3), 320-333.

Indenrigs- og Sundhetsministeriet (2011). Generelle tilskud til regionerne 2012. København K. Denmark. (General Contributions to the Regions 2012). Available from: http://oim.dk/media/61729/Generelle-tilskud-til-regionerne-2012.pdf.

Information Services Division, NHS National Services Scotland (2015). Resource Allocation Formula. Results for Financial Year 2015/16. Edinburgh, Scotland. Available from: http://www.isdscotland.org/Health-Topics/Finance/Publications/2015-02-24/2015-02-24-

NRAC-Summary.pdf?

Kahl H, Dortschy R, Ellsäßer G. (2007). Verletzungen bei Kindern und Jugendlichen (1-17 Jahre) und Umsetzung von persönlichen Schutzmaßnahmen: Ergebnisse des bundesweiten Kinderund Jugendgesundheitssurveys (KiGGS) (Injuries among Children and Adolescents (1-17 years) and Implementation of Safety Measures. Results of the Nationwide German Health Interview and Examination Survey for Children and Adolescents (KiGGS). Bundesgesundheitsblatt Gesundheitsforschung Gesundheitsschutz. 2007, 50(5/6), 718-727. doi: 10.1007/s00103-007-0233-7.

Magnussen, J., Hagen, T., and Kaarboe, O. (2007). Centralized or Decentralized? A case study of Norwegian Hospital Reform. Social Science \& Medicine, 64(10), 2129-2137.

Magnussen, J. (2010). Equal Access for Equal Need? Constructing and Implementing a CapitationBased Formula for the Distribution of Health Care Resources in Norway. International Journal of Circumpolar Health, 69(5), 448-461.

Ministry of Health and Care Services (2008). Fordeling av Inntekter mellom Regionale Helseforetak. NOU 2008:2. Oslo, Norway. (Allocation of Resources among Regional Health Enterprises). Available from: https://www.regjeringen.no/contentassets/d36f4ddb70f04af19182a582d 0878da0/no/pdfs/nou200820080002000dddpdfs.pdf 
Mörk E., Sjögren A., and Svaleryd, H. (2014). Hellre rik och frisk. Om familjebakgrund och barns hälsa. (Rather rich and healthy. Family characteristics and children's health). SNS Förlag, Stockholm.

NHS England Analytical Services (2014). Technical guide to the formulae for 2014-15 and 201516 revenue allocations to clinical commissioning groups and area teams. Leeds, England. Available from: http://www.england.nhs.uk/wp-content/uploads/2014/03/tech-guide-revallocs.pdf

Reiss F. (2013). Socioeconomic Inequalities and Mental Health Problems in Children and Adolescents: A Systematic Review. Social Science \& Medicine, 90, 24-31.

Statistics Norway (2012). Innvandring og innvandrere (Immigration and immigrants), http://www.ssb.no/innvandring/ (downloaded 09.01.13).

Statistics Sweden (2015). Kommunalekonomisk utjämning. Utjämningsåret 2015. Stockholm, Sweden. (Economic equalization for local governments, 2015). Available from: http://www.scb.se/sv_/Hitta-statistik/Statistik-efter-amne/Offentlig-ekonomi/Finanser-forden-kommunala-sektorn/Kommunalekonomisk-utjamning-och-utjamning-av-LSS-kostnader/

Steptoe, A., and Marmot, M. (2004). Socioeconomic status and coronary heart disease: A psychobiological perspective. In L. J. Waite (Ed.), Aging, health and public policy: Demographic and economic perspectives (Supplement to Vol. 30). New York: Population Council.

Van Doorslaer, E., and Masseria, C. (2004). Income-Related Inequality in the Use of Medical Care in 21 OECD Countries. OECD Health Working Papers No. 14, OECD.

(C) 2017 by the author(s). This article is an open access article distributed under the terms and conditions of the Creative Commons Attribution license (http://creativecommons.org/licenses/by/4.0/). 